ISSN (Print) : :1412-7601

ISSN (Online) : 2654-8712

Volume 7, No.1 Maret 2021

EKONOBIS

http://www.ekonobis.unram.ac.id

\title{
ANALISIS SEKTOR EKONOMI UNGGGULAN SAAT INI DAN DI MASA DEPAN DALAM UPAYA PENGURANGI JUMLAH KEMISKINAN DI KABUPATEN LOMBOK UTARA PROVINSI NUSA TENGGARA BARAT
}

\author{
Muhammad Alwi, Putu Karismawan, I Dewa Ketut Yudha S
}

Universitas Mataram

\begin{tabular}{l}
\hline ARTICLE INFO \\
\hline Keywords: \\
Basic (Leading) Sektor \\
and Poverty Reduction
\end{tabular}

Kata Kunci:

Sektor Unggulan dan

Pengurangan Kemiskinan

ABSTRACT : The objectives of this research ara firstly, to idetified basic or leading economic sektors at present and in the future that can be developed to decrease of poverty; secondly, to analysis corelation between growth and poverty and mapping of poverty at all subdistrict in North Lombok. The Static Location Quotient (SLQ) combined with Dynamic Location Quotient (DLQ), simple regression and frequency distribution are use to analysis data of both Product Demestic Bruto of North Lombok and West Nusa Tenggara Province and amount of poverty people in North Lombok. Base on the SLQ -DLQ analysis there are 6 Basic or leading sektors: 1) Electricity and Gas supply; 2) water supply, severage, waste management and remediation activities; 3) construction; 4) information and communication; 5) Public administration and defence, compulsory social security; 6) human health and social work activities. Base on simple regression analysis there are negative liniear correlation between gorwth and poverty that mean poverty will decrease when ecocomic growth increase. Base on poverty mapping that Tanjung sub district as the highest amount poverty poepole in North Lombok with 2.594 peoples that spread at 7 rural area. Sokong is the highest of the 7 rural area with 925 poverty peoples.

ABSTRAK: Tujuan penelitian ini pertama, mengindentifikasi sektor-sektor ekonomi yang merupakan sektor unggulan saat ini dan masa depan yang dapat dikembangkan untuk mengurangi jumlah penduduk miskin; kedua, menganalisis pengaruh pertumbuhan ekonomi terhadap jumlah penduduk miskin, dan memetakan kemiskinan di ke 5 kecamatan yang ada di Kabupaten Lombok Utara. Metode anailisis yang digunakan dalam penelitian ini adalah $S L Q-D L Q$, regresi Sederhana dan tabulasi distribusi frekwensi dengan menggunakan data PDRB Kabupaten Lombok Utara, jumlah penduduk miskin dan PDRB Provinsi Nusa Tenggara Barat. Berdasarkan hasil perhitungan SLQ digabungkan DLQ diketahui bahwa terdapat 6 sektor ekonomi unggulan pada saat sekarang dan beberapa tahun kedepana, yaitu 1).Pengadaan listrik dan gas, 2). Pengadaan air, pemgolahan sampah limbah, dan daur ulang, 3). Kontruksi, 4). Informasi dan komunikasi, 5). Administrasi Pemerintahan, pertahanan dan Jaminan Sosial Wajib, 6.) Jasa Kesehatan dan Kegiatan sosial. Berdasarkan analisis regresi sederhana di dapat bahwa pertumbuhan ekonomi dan perkembangan jumlah penduduk miskin menunjukkan huhubungan yang berlawanan arah, artinya jika pertumbuhan ekonomi meningkat maka jumlah penduduk miskin menurun. Peta Jumlah penduduk miskin di Kabupaten Lombok Utara menunjukan bahwa jumlah penduduk miskin yang terbanyak adalah di Kecamatan Tanjung dengan jumlah 2594 orang yang tersebar pada 7 Desa dan Desa yang terbanyak penduduk miskin terdapat di Desa Sokong sejumlah 932 orang dan Desa Sigar Penjalin sejumlah 925 orang penduduk miskin.

Corresponding Author:

Alamat : Program Studi Ekonomi Pembangunan, Fakultas Ekonomi dan Bisnis, Universitas Mataram, Jln. Majapahit No. 62 Mataram.

e-mail:m.alwi@unram.ac.id 


\section{PENDAHULUAN}

\section{Latar Belakang}

Perjalanan pembangunan ekonomi telah menimbulkan berbagai macam perubahan terutama pada struktur perekonomian. Perubahan struktur ekonomi merupakan salah satu karakteristik yang terjadi dalam pertumbuhan ekonomi pada hampir setiap negara maju. Berdasarkan catatan sejarah, tingkat pertumbuhan sektoral ini termasuk pergeseran secara perlahan dan kegiatankegiatan pertanian menuju ke kegiatan non pertanian dan akhir-akhir ini dari sektor industri ke sektor jasa (Arsyad, 1995:75). Pembangunan daerah sebagai bagian integral dari pembangunan nasional merupakan suatu proses perubahan yang terencana dalam upaya mencapai sasaran dan tujuan untuk meningkatkan kesejahteraan masyarakat yang didalamnya melibatkan seluruh kegiatan yang ada melalui dukungan masyarakat di berbagai sektor. Pembangunan daerah harus sesuai dengan kondisi potensi serta aspirasi masyarakat yang tumbuh dan berkembang. Apabila pelaksanaan prioritas pembangunan daerah kurang sesuai dengan potensi yang dimiliki oleh masing-masing daerah, maka pemanfaatan sumber daya yang ada menjadi kurang optimal. Keadaan tersebut dapat mengakibatkan lambatnya proses pertumbuhan ekonomi daerah yang bersangkutan yang pada gilirannya memperlambat perluasan kesempatan kerja dan memperlambat penanggulangan kemiskinan.

Proses lajunya pertumbuhan ekonomi suatu daerah dituunjukkan dengan menggunakan tingkat pertambahan PDRB (Produk Domestik Regional Bruto), sehingga tingkat perkembangan PDRB per kapita yang dicapai masyarakat seringkali sebagai ukuran kesuksesan suatu daerah dalam mencapai cita-cita untuk menciptakan pembangunan ekonomi. Secara makro. Pertumbuhan dan peningkatan PDRB dari tahun ke tahun merupakan indikator dari keberhasilan pembangunan daerah. Besar kecilnya pertumbuhan ekonomi sangat tergantung produktivitas dari 17 sektor ekonomi yang membentuk PDRB suatau daerah.

Semakin besar sumbangan yang diberikan oleh masing-masing sektor ekonomi terhadap PDRB suatu daerah maka akan dapat mencapai pertumbuhan ekonomi kearah yang lebih baik. Pertumbuhan ekonomi dilihat dari PDRB merupakan salah satu indikator untuk melihat keberhasilan pembangunan.

Meningkatnya pertumbuhan ekonomi melalui indikator Produk Domestik 
Regional Bruto (PDRB) yang berarti pula akan meningkatkan kesejahteraan dan kemakmuran rakyat karena kegiatan ekonomi semakin luas yang dapat menampung tenaga kerja yang akhir dapat menjadi salah satu upaya penanggulangan kemiskinan. Untuk meningkatkan pertumbuhan ekonomi di daerah-daerah peran pemerintah sangat diperlukan yaitu dalam pembuatan strategi dan perencanaan pembangunan daerah, dengan memperhatikan pergeseran sektor ekonomi dari tahun ke tahun.

Provinsi Nusa Tenggara Barat terdiri atas 2 pulau besar yaitu Pulau Lombok terdapat 5 Kabupaten/Kota dan Pulau Sumbawa terdapat juga 5 Kabupaten/Kota.

Adapun jumlah penduduk dan persetase jumlah penduduk miskin di setiap Kabuten/Kota di Provinsi Nusa Tenggara Barat dapat dilihat pada tabel berikut ini :

Tabel 1. Jumlah penduduk, Jumlah Penduduk miskin dan persentase Jumlah Penduduk Miskin Di Provinsi Nusa Tenggara Barat Tahun 2017.

\begin{tabular}{|l|l|l|l|l|}
\hline No & \multicolumn{1}{|c|}{ Kabupaten/Kota } & $\begin{array}{c}\text { Jumlah } \\
\text { Penduduk } \\
\text { (Jiwa) }\end{array}$ & $\begin{array}{c}\text { Jumlah } \\
\text { Penduduk } \\
\text { miskin (Jiwa) }\end{array}$ & $\begin{array}{c}\text { Prsentase } \\
\text { jumlah } \\
\text { penduduk } \\
\text { miskin }\end{array}$ \\
\hline 1 & Lombok Utara & 233.691 & 74.921 & 32,06 \\
\hline 2 & Lombok Timur & $1,289.907$ & 171.299 & 13,28 \\
\hline 3 & Lombok Barat & 713.848 & 117.494 & 16,46 \\
\hline 4 & Lombok Tengah & 1.035 .355 & 158.207 & 15,31 \\
\hline 5 & Kota Mataram & 419.506 & 40.063 & 9,55 \\
\hline 6 & Sumbawa Barat & 135.031 & 21.550 & 15,96 \\
\hline 7 & Sumbawa & 509.234 & 80.510 & 15,81 \\
\hline 8 & Bima & 524.677 & 79.226 & 15,10 \\
\hline 9 & Kota Bima & 141.294 & 13.098 & 9,27 \\
\hline 10 & Dompu & 214.795 & 28.782 & 13,46 \\
\hline
\end{tabular}

Sumber: BPS Diolah

Berdasarkan pada table 1 di atas dapat diketahui bahwa dari segi persentase jumlah penduduk miskin dari jumlah penduduk Kabutan dan Kota, maka yang tertinggi persentasenya adalah Kabupaten Lombok Utara. Persentase jumlah penduduk miskin di Kabupaten Lombok Utara diperkirakan akan semakin meningkat pada tahun 2018 sampai tahun 2020. Hal ini karena Provinsi Nusa Tenggara Barat dilanda gempa bumi dan yang paling parah di Kabupaten Lombok Utara.

Untuk dapat mengatasi hancuranya sarana dan prasarana sosial dan ekonomi serta pemberdayaan penduduk meskin tentu 
memperlukan dana yang cukup besar. Untuk itu perlu menggali potensi ekonomi daerah yang harus dikembangkan seperti mengarahkan investasi pada sektor unggulan untuk dapat meningkatkan pertumbuhan ekonomi yang pada gilirannya akan memperluas kesempatan kerja sehingga jumlah penduduk miskin dapat dikurangi. Kemudian agar pemberdayaan mayarakat miskin terarah maka sangat diperlukan pemetaan penduduk miskin dengan membuat strategi pengurangan penduduk miskin.

\section{Rumusan Masalah}

Berdasarkan latar belakang di atas, maka rumusan masalah adalah sebagai berikut:

a. Identifikasi sektor ekonomi yang mana merupakan sektor unggulan saat ini dan masa depan yang dapat dikembangkan untuk mengurangi jumlah penduduk miskin di Kabupaten Lombok Utara.

b. Menganalisis pengaruh pertumbuhan ekonomi terhadap jumlah penduduk miskin di Kabupaten Lombok Utara.

c. Bagaimana peta kemikinan pada ke 5 kecamatan yang ada di Kabupaten Lombok Utara.

\section{Tujuan Penelitian}

a. Untuk mengidentifikasi sektor ekonomi unggulan saat ini dan masa depan dalam upaya mengurangi penduduk meskin di Kabupaten Lombok Utara.

b. Untuk menganalisis pengaruh pertumbuhan ekonomi terhadap jumlah penduduk miskin di Kabupaten Lombok Utara.

c. Untuk mengetahui peta jumlah penduduk miskin pada pada 5 kecamatan di Kabupaten Lombok Utara.

\section{KAJIAN PUSTAKA}

\section{Pertumbuhan Ekonomi}

Pertumbuhan ekonomi diartikan sebagai kenaikan PDRB tanpa memndang apakah kenaikan itu lebih besar atau lebih kecil dari tingkat pertumbuhan penduduk atau apakah perubahan struktur ekonomi terjadi atau tidak. (Arsyad, 1997:13). Jika ingin mengetahui tingkat pertumbuhan ekonomi kita harus membandingkan pendapatan nasional dari tahun ke tahun.. Suatu perekonomian dikatakan mengalami pertumbuhan atau perkembangan jika tingkat kegiatan ekonomi yang dicapai lebih tinggi dari sebelumnya.

\section{Pengertian Sektor Unggulan}

Sektor unggualan merupakan sektor potensial yang dimiliki oleh suaatu wilayah karena merupakan sektor basis yang dapat dikembangkan atau dimaksimalkan untuk menjadi penentu perkembangan ekonomi 
suatu wilayah. Pada dasarnya sektor unggulan suatu daerah dapat memberikan kontribusi yang besar pada daerah, bukan hanya untuk daerah itu sendiri tetapi juga memenuhi kebutuhan daerah lain. Semua kegiatan lain bukan kegiatan basis termasuk kegiatan/sektor service atau pelayanan, tetapi untuk tidak menciptakan pengertian yang keliru tentang arti service maka disebut juga sektor non basis atau bukan sektor unggulan (Tarigan, 2012). Sektor unggulan adalah sektor yang mampu mendorong pertumbuhan atau perkembangan bagi sektor-sektor lainnya, baik sektor yang mensuplai inputnya maupun sektor yang memamfaatkan outnya sebagaiinput dalam proses produksi (Widodo, 2006).

\section{Teori Ekonomi Basis}

Teori basis ekonomi merupakan faktor penentu utama pertumbuhan ekonomi suatu daerah adalah berhubungan langsung dengan permintaan barang dan jasa luar daerah. Dalam teori basis ekonomi (economic base) bahwa semua wilayah merupakan sebuah sistem sosio ekonomi yang terpadu. Teori inilah yang mendasari teknik Loqation Quotient, yaitu teknik yang membantu dalam menentukan kapasitas ekspor perekonomian daerah dan derajat keswasembadaan (selfsufficiency) suatu sektor. Menurut Sjafrizal
(2008, 89) bahwa sektor basis adalah sektor yang menjadi tulang punggung perekonomian daerah karena mempunyai keuntungan kompetitif (Competitive Advantage) yang cukup tinggi. Sedangkan sektor non basis adalah sektor-sektor lainnya yang kurang potensial tetapi berfungsi sebagai penunjang sektor basis atau service industries. Teknik LQ dapat dibedakan menjadi dua, yaitu SLQ (Static Location Quotient, SLQ) dan DLQ dinamis (Dynamic Locationa Quotient).

\section{Pengertian Kemiskinan dan Garis Kemiskinan}

Secara etimologis, kemiskinan berasal dari kata "miskin" yang artinya tidak berharta benda dan serba kekurangan. Definisi kemiskinan menurut beberapa ahli memiliki perbedaan pandangan. Secara umum kemiskinan diartikan sebagai tidak adanya kenyamanan hidup dan tidak terpenuhinya kebutuhan-kebutuhan dasar (Wirasasmita, dkk, 2002). Departemen Sosial dan Biro Pusat Statistik, mendefinisikan kemiskinan dari perspektif kebutuhan dasar. Kemiskinan sebagai ketidakmampuan individu dalam memenuhi kebutuhan dasar minimal untuk hidup layak (Nurhadi, 2007: 13). Lebih lanjut Nurhadi (2007: 13) menyebutkan kemiskinan merupakan sebuah kondisi yang berada di bawah garis 
nilai standar kebutuhan minimum, baik untuk makanan dan non-makanan yang disebut garis kemiskinan (povertyline) atau batas kemiskinan (povertytresshold).

Garis kemiskinan adalah sejumlah rupiah yang diperlukan oleh setiap individu untuk dapat membayar kebutuhan makanan secara 2.100 kilo kalori per orang per hari dan kebutuhan non-makanan yang terdiri dari perumahan, pakaian, kesehatan, pendidikan, transportasi, serta aneka barang dan jasa lainnya.

Berkaitan dengan garis kemiskinan banyak indikator yang dapat dipergunakan baik untuk skala internasional maupun nasional. Khusus di Indonesia batasan garis kemiskinan yang dapat dipergunakan seperti Sayogyo (1971) yang membedakan penduduk Miskin, Miskin Sekali dan Paling Miskin untuk penduduk pedesaan dan perkotaan yang melihat tingkat pengeluaran ekulivalen beras perorang per tahun (kg) masing-masing :

Tabel 2. Kriteria Kemiskinan Perkotaan dan Pedesaan

\begin{tabular}{|l|c|c|}
\hline \multicolumn{1}{|c|}{ Kriteria } & $\begin{array}{c}\text { Desa } \\
(\mathrm{kg})\end{array}$ & $\begin{array}{c}\text { Kota } \\
(\mathrm{kg})\end{array}$ \\
\hline Miskin & 480 & 320 \\
\hline Miskin Sekali & 360 & 240 \\
\hline Paling Miskin & 270 & 180 \\
\hline
\end{tabular}

\section{METODE PENELITIAN}

\section{Jenis Penelitian}

Jenis penelitian yang digunakan adalah penelitian deskriptif kuantitatif yaitu suatu metode dalam meneliti status kelompok manusia, suatu objek, suatu kondisi, suatu system pemikiran ataupun suatu peristiwa pada masa sekarang guna membuat diskripsi, gambaran atau lukisan secara sistimatis, factual dan akurat mengenai fakta-fakta,sifat-sifat dan hubungan antara fenomena-fenomena yang diselidiki, (Nazir, 2011: 54).

\section{Lokasi Penelitian}

Lokasi penelitian bertempat di Kabupaten Lombok Utara yang dipilih dari 10 kabupaten /Kota yang ada di Provinsi Nusa Tenggara Barat. Pemilihan lokasi penelitian ini karena Kabupaten Lombok Utara memiliki jumlah penduduk miskin dengan persentase yang tersebesar dari jumlah penduduknya dibandingkan dengan 9 Kabupaten/Kota yang ada di Provinsi Nusa Tenggara Barat.

\section{Metode Pengumpulan Data}

Mengumpulan data dilakukan dalam penelitian ini adalah metode kasus (case study) yaitu penelitian tentang suatu status subjek yang berkenaan dengan suatu pase spesifik atau khas dari keseluruhan personalitas di mana subjek ini bisa terdiri dari kelompok, lembaga 
maupun masyarakat yang tujuannya untuk memberikan gambaran secara mendetail.

\section{Tehnik Pengumpulan Data}

Tehnik pengumpulan data yang digunakan adalah:

a. Studi Kepustakaan yaitu tehnik pengumpulan data dengan melakukan studi tantang data-data yang bersumber atau diperoleh dari bahan bacaan yang ada hubungannya dengan masalah yang ditiliti.

b. Dokumentasi yaitu tehnik pengumpulan data dengan cara mengumpulkan data yang tersedia pada instansi-instansi terkait dengan penelitian ini untuk didokumentasikan, dicacat atau dianalisa sesuai dengan kebutuhan penelitian.

\section{Jenis Data}

Jenis data yang digunakan dalam penelitian ini adalah data kuantatif berupa data sekunder. Data tersebut adalah data PDRB pada setiap sektor ekonomi yang membentuk PDRB pada Kabupaten Lombok Utara, PDRB Provinsi Nusa Tenggara Barat dan data jumlah penduduk miskin perkecamatan

\section{Sumber Data}

Data sekunder yang digunakan dalam penelitian ini bersumber dari Kantor BPS NTB dan Kantor Statistik Kabupaten
Lombok Utara dan pada Kantor Kecamatan, Kantor Lurah dan Desa yang ada di Kabupaten Lombok Utara dan Instansi pemerintah lainnya.

\section{Prosedur Analisis}

Untuk mengetahui sektor unggulan saat ini dan tahun depan dilakukan dengan memadukan antara Analisis Location Quotient Statis (SLQ) dengan Location Quotient Dinamic (DLQ), adapun kedua analisis tersebut sebagai berikut:

1. SLQ (Static Location Quotient) biasa disebut SLQ.

Adapun rumusan yang dipakai dalam analisis Static location quotient:

$$
\text { Formula } L Q_{i}=\frac{\frac{V_{i j}}{V_{i}}}{\frac{V_{i n}}{V_{n}}}
$$

Dimana :

LQ $=$ Location Quotient sektor ekonomi ke i pada di Kabupaten Lombok Utara

vij $=$ PDRB Sektor ekonomi $\mathrm{i}$ pada Kabupaten Lombok Utara

vi =PDRB Kabupaten Lombok Utara

Vin =PDRB sektor ekonomi ke i Provinsi

Nusa Tenggara Barat

Vn $\quad=$ PDRB Nusa Tenggara Barat

Dengan menggunakan kriteria pengukuran yang dikemukakan oleh Bandavid-Val (1991 : 74) maka setelah dihitung nilai LQ tersebut mengandung pengertian sebagai berikut : 
a. Jika LQ $>1$ menunjukkan sub sektor ekonomi ke-i pada Kabupaten Lombok Utara tergolong sektor basis atau lebih spesialis dari pada sektor yang sama di pada tingkat Provinsi.

b. Jika LQ <1 menunjukkan sektor ekonomi ke-i pada Kabupaten Lombok Utara tergolong sektor non basis, atau sektor i kurang spesialis dari pada sektor yang sama pada Provinsi Nusa Tenggara Barat.

c. Jika $L Q=1$ menunjukkan keswasembadaan (self-sufficiency) sub sektor ekonomi i, di Kabupaten Lombok Utara memiliki spesialis yang sama dengan sektor yang sama pada Provinsi Nusa Tenggara Barat.

Metode LQ Statis mempunyai keterbatasan karena besifat statis dan hanya digunakan untuk mengestimasi perubahan sektor unggulan pada tahun tertentu saja. Untuk mengatasi keterbatasan metode LQ statis, maka akan digunakan perpaduan anatara metode LQ Dinamis (DLQ)yang mampu mengakomodasi perubahan struktur ekonomi wilayah dalam kurun waktu tertentu. Menurut Saharuddin (2006) DLQ memasukan laju pertumbuhan rata-rata terhadap masing-masing nilai tambah sektoral maupun PDRB untuk kurun waktu antara 0 sampai tahun $\mathrm{t}$.

2. DLQ (Dinamic Location Quotient)

Bentuk persamaan matematis DLQ adalah dengan formula sebagai berikut:

DLQiJ $=\frac{\frac{(1+g i j)}{(1+g j)}}{\frac{(1+G j)}{(1+G)}}=\frac{I P P S i j}{I P P S i}$

Dimana :

DLQiJ = Dinamic Location Quotientsub sektor ekonomi i di Kabutan J

IPPSij = Indeks potensi perkembangan sektor I di Kabuten J

IPPSi = Indeks potensi perkembangan sektor ekonomi i di wilayah referensi

Gij = Laju pertumbuhan sektor ekonomi $\mathrm{i}$ di daerah j

$\mathrm{Gi}=$ Laju pertumbuhan sektor ekonomi $\mathrm{i}$ di wilayah referensi

gi = Rata-rata laju pertumbuhan di daerah J

$\mathrm{Gi}=$ Rata-rata laju pertumbuhan $\mathrm{di}$ wilayah referensi

Jika DLQ = 1 berarti laju pertumbuhan sektor i terhadap laju pertumbuhan PDRB didaerah (J) sebanding dengan laju pertumbuhan sektor tersebut dalam PDRB wilayah referensi. Jika DLQ $<1$ berarti proporsi laju pertumbuhan sektor i terhadap laju pertumbuhan PDRB daerah J lebih rendah dibandingkan proporsi laju sektor tersebut terhadap PDRB wilayah 
wilayah referensi. Sebaliknya jika DLQ $>1$ bararti proporsi laju pertumbuhan sektor $\mathrm{i}$ terhadap PDRB daerah J lebih cepat dibandingkan dengan proporsi laju pertumbuhan sektor tersebut terhadap PDRB wilayah.

Selanjutnya klasifikasi sektor berdasarkan nilai LQ dan DLQ di Kabupaten Lombok Utara dapat dilakukan seperti pada tabel 3 berikut :

Tabel 3. Klasifikasi sektor berdasarkan nilai LQ dan DLQ pada setiap Kecamatan di Kabupaten Lombok Utara

\begin{tabular}{|l|l|l|}
\hline KRITERIA & LQ.> 1 & LQ $<1$ \\
\hline DLQ $>1$ & $\begin{array}{l}\text { Sektor } \\
\text { Unggulan }\end{array}$ & $\begin{array}{l}\text { Sektor } \\
\text { andalan }\end{array}$ \\
\hline DLQ $<1$ & $\begin{array}{l}\text { Sektor } \\
\text { Prospektif }\end{array}$ & $\begin{array}{l}\text { Sektor } \\
\text { tertinggal }\end{array}$ \\
\hline
\end{tabular}

Keterangan :

Berdasarkan matriks di atas dapat diketahui bahwa sektor unggulan dengan syarat $\mathrm{DLQ}>1$ dan $\mathrm{LQ}>1$, merupakan sektor pada saat ini merupakan sektor unggulan dan tetap unggul pada beberapa tahun ke depan. Untuk sektor andalan dengan syarat DLQ $>1$ dan $L Q<1$ merupakan sektor yang saat ini belum unggul tetapi dalam beberapa waktu ke depan berpotensi unggul. Untuk sektor prospektif dengan syarat $L Q>1$ dan $D L Q<$ 1 sektor yg pada saat ini unggul tetapi tidak berpotensi unggul pada beberapa tahun ke depan, sedangkan sektor tertinggal dengan syarat $L Q<1$ dan $D L Q<1$ dinyatakan tidak unggul untuk saat ini dan pada beberapa waktu ke depanpum belum berpotensi untuk menjadi sektor unggul. Untuk menganalisis pengaruh Perutumbuhan Ekonomi terhadap jumlah penduduk miskin dengan rumus regresi sederhana sebagai berikut:

Rumus dari dari analisis regresi linear sederhana adalah sebagai berikut:

$$
Y^{\prime}=a+b X
$$

Keterangan:

$Y=$ subyek dalam variabel dependen (Jumlah penduduk miskin)

$\mathrm{a}=$ harga $\mathrm{Y}$ ketika harga $\mathrm{X}=0$ (harga konstan)

$b=$ angka arah atau koefisien regresi, yang menunjukkan angka peningkatan ataupun penurunan variabel dependen yang didasarkan pada perubahan variabel independen. Bila (+) arah garis naik, dan bila (-) maka arah garis turun.

$X$ = subyek pada variabel independen (Pertumbuhan Ekonomi)

Secara teknik harga b merupakan tangent dari perbandingan antara panjang garis variabel dependen, setelah persamaan regresi ditemukan.

Untuk membuat peta kemiskinan pada setiap Kecamatan yang ada di Kabupaten Lombok Utara digunakan Analisis Tabel Distribusi Frekwensi 
HASIL DAN PEMBAHASAN

Identifikasi Sektor Unggulan, Andalan, Prospektif dan sektor Tertinggal

Penggabungan antara analisis SLQ (Location Quetient Statis) dan DLQ Penelitian ini bertujuan untuk mengetahui sektor unggulan, sektor andalan, sektor prospektif dan sektor tertinggal yang ada di Kabupaten Lombok Utara dengan kriteria :

Tabel 4. Klasifikasi sektor berdasarkan nilai LQ dan DLQ pada setiap Kecamatan di Kabupaten Lombok Utara

\begin{tabular}{|l|l|l|}
\hline KRITERIA & \multicolumn{1}{|c|}{ LQ. $>1$} & LQ $<1$ \\
\hline DLQ $>1$ & $\begin{array}{l}\text { Sektor } \\
\text { Unggulan }\end{array}$ & $\begin{array}{l}\text { Sektor } \\
\text { andalan }\end{array}$ \\
\hline DLQ $<1$ & $\begin{array}{l}\text { Sektor } \\
\text { Prospektif }\end{array}$ & $\begin{array}{l}\text { Sektor } \\
\text { tertinggal }\end{array}$ \\
\hline
\end{tabular}

Keterangan :

Berdasarkan matriks di atas dapat diketahui bahwa sektor unggulan dengan Location Quetient Dinamis) dalam

syarat $\mathrm{DLQ}>1$ dan $\mathrm{LQ}>1$, merupakan sektor pada saat ini merupakan sektor unggulan dan tetap unggul pada beberapa tahun ke depan. Untuk sektor andalan dengan syarat DLQ $>1$ dan $L Q<1$ merupakan sektor yang saat ini belum unggul tetapi dalam beberapa waktu ke depan berpotensi unggul. Untuk sektor prospektif dengan syarat $L Q>1$ dan $D L Q<$ 1 sektor yg pada saat ini unggul tetapi tidak berpotensi unggul pada beberapa tahun ke depan, sedangkan sektor tertinggal dengan syarat $\mathrm{LQ}<1$ dan $\mathrm{DLQ}<1$ dinyatakan tidak unggul untuk saat ini dan pada beberapa waktu ke depanpum belum berpotensi untuk menjadi sektor unggul.

Berdasarkan pada tabel 4 di atas dapat dibuat klasifikasi sektor unggulan, andalan, Prospektif dan sektor tertinggala adalah nampak pada tabel berikut :

Tabel 5. Sektor Ungggulan, Sektor Andalan, Sektor Prospektif dan Sektor Tertinggal

\begin{tabular}{|c|c|c|}
\hline Kriteria & SLQ > 1 & SLQ $<1$ \\
\hline $\mathrm{DLQ}>1$ & $\begin{array}{l}\text { Sektor Unggulan : } \\
\text { Sektor: } \\
\text { Pengadaan Listrik dan Gas } \\
\text { Pengadaan Air, Pemgolahan } \\
\text { Sampah, Limbah, dan Daur Ulang } \\
\text { Kontruksi } \\
\text { Informasi dan komunikasi } \\
\text { Adm Pemerintahan, pertahanan } \\
\text { Jaminan Sosial Wajib } \\
\text { Jasa Kesehatan dan Kegiatan } \\
\text { sosial }\end{array}$ & $\begin{array}{l}\text { Sektor Ekonomi Andalan : } \\
\text { Petambangan dan galian } \\
\text { Industri pengolahan } \\
\text { Jasakesehatan dan kegiatan sosial, }\end{array}$ \\
\hline $\mathrm{DLQ}<1$ & $\begin{array}{l}\text { Sektor Ekonomi Propektif } \\
\text { Perdagangan besar dan eceran, } \\
\text { Reparasi mobil dan motor }\end{array}$ & $\begin{array}{l}\text { Sektor Ekonomi Teringgal: } \\
\text { Transportasi dan Pergudangan } \\
\text { Jasa Keuangan dan asuransi }\end{array}$ \\
\hline
\end{tabular}




\begin{tabular}{|l|l|l|}
\hline Penyediaan Akomodasi dan & \\
Makanan & \\
Jasa Perusahaan & Real estate & \\
Jasa pendidikan & Jasa Lainnya & \\
\hline
\end{tabular}

Sumber data: diolah dari tabel

Berdasarkan pada tabel di atas diketahui ada 6 sektor ekonomi unggulan, 3 sektor ekonomi andalan, 6 sektor ekonomi propestif dan 2 sektor ekonomi tertinggal. Dengan melihat kondisi sektor ekonomi tersebut diatas, maka pemerintah dapat membuat perencanaan dalam membuat strategi pembangunan ekonomi baik dengan kondisi daerah Kabupaten Lombok utara. Untuk dapat mendorong pertumbuhan ekonomi yang tinggi, maka diperlukan strategi pembangunan dengan memprioritaskan pengembangan sektor unggulan.

\section{Pertumbuhan Ekonomi Dan Angka} Kemiskinan Di Kabupaten Lombok Utara Kabupaten Lombok Utara sejak ditetapkan sebagai daerah otonom, dimana secara administratif terpisah dengan Kabupaten Lombok Barat, mengerahkan seluruh sumberdaya pembangunan untuk mengejar ketertinggalan dengan kabupaten/kota lain di Provinsi Nusa Tenggara Barat dan telah menunjukkan hasil yang progresif. Ini terlihat dari pertumbuhan ekonomi yang dicapai sampai tahun 2017. Bencana alam berupa gempa bumi yang terjadi tahun 2018 yang meluluh lantakkan hampir seluruh prasarana ekonomi di Lombok Utara, sehingga kegiatan ekonomi diberbagai sektor stagnan. Ini terlhat pada angka pertumbuhan ekonomi tahun 2018 mencapai $-0,86 \%$.

Tabel 6. Pertumbuhan Ekonomi, Garis Kemiskinan, Penduduk Miskin di Kabupaten Lombok Utara, Tahun 2012-2018

\begin{tabular}{|l|c|c|c|c|}
\hline Tahun & $\begin{array}{c}\text { Pertumbuhan } \\
\text { ekonomi (\%) }\end{array}$ & $\begin{array}{c}\text { Garis Kemiskinan } \\
\text { (Rp/Kapita/ bulan) }\end{array}$ & $\begin{array}{c}\text { Penduduk Miskin } \\
\text { (X1000 jiwa) }\end{array}$ & $\begin{array}{c}\text { Penduduk Miskin } \\
\text { (\%) }\end{array}$ \\
\hline 2012 & 4,08 & 315.276 & 73,48 & 35,97 \\
\hline 2013 & 4,12 & 332.073 & 75,45 & 35,87 \\
\hline 2014 & 4,08 & 347.150 & 72,19 & 34,27 \\
\hline 2015 & 4,11 & 363.367 & 72,28 & 34,13 \\
\hline 2016 & 4,59 & 387.265 & 71,02 & 33,21 \\
\hline 2017 & 6,14 & 398.702 & 69,24 & 32,06 \\
\hline 2018 & $-0,86$ & 416.705 & 62,86 & 28,83 \\
\hline
\end{tabular}


Berdasarkan pada table di atas dapat dibuat grafik di bawah ini:

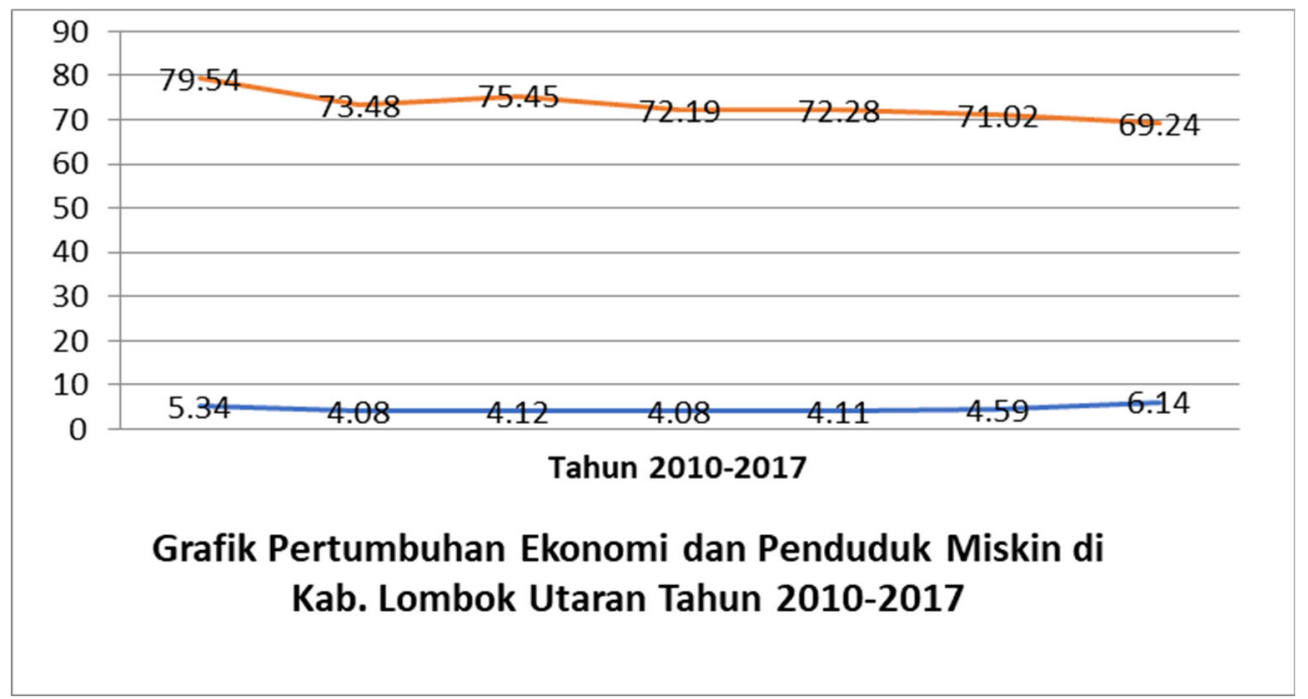

Sumber: BPS Kabupaten Lombok Utara

Secara umum tampak pada grafik bahwa ada korelasi dengan arah yang berlawanan antara laju pertumbuhan ekonomi dengan jumlah penduduk miskin. Grafik garis pertumbuhan ekonomi dengan trend meningkat di satu sisi dan di sisi lain grafik garis jumlah penduduk miskin menunjukkan arah pergerakan denga trend menurun. Secara teoritis terdapat hubungan antara peningkatan pertumbuhan ekonomi dengan penurunan angka kemiskinan. Peningkatan pertumbuhan ekonomi cerminan dalam keberhasilan pembangunan ekonomi di berbagai sektor berdampak pada peningkatan lapangan kerja dan pendapatan dan bermuara pada menurunnya jumlah penduduk miskin.

Kegiatan pembangunan di samping memacu pertumbuhan ekonomi juga untuk menurunkan angka kemiskinan.
Seiring dengan keberhasilan dalam memacu pertumbuhan ekonomi di Kabupaten Lombok Utara jumlah penduduk miskin terus menurun, dari 86.340 jiwa $(43,14 \%)$ tahun 2010 menjadi 69.240 jiwa (32,06\%) tahun 2017.

Hasil regresi menunjukkan hubungan yang berlawanan arah antara pertumbuhan ekonomi dan jumlah penduduk miskin dengan hasil regresi $Y^{\prime}=65,87-0,42 X$ artinya bahwa setiap capaian peningkatan pertumbuhan ekonomi sebesar $1 \%$ dapat menurunkan penduduk miskin sebesar 420 jiwa. Hasil korelasi $r=-10$ dan koefisien Determinasi sebar 1\%, menunjukkan bahwa penurunan jumlah penduduk miskin merupakan resultante dari berbagai faktor, antara lain stabilitas politik di Kabupaten Lombok Utara, tingkat keamanan, kondisi perekonomian nasional dan global. Kondisi global sangat 
menentukan aktifitas kegiatan ekonomi di Lombok Utara, mengingat sektor pariwisata dengan andalan tiga Gili, yaitu Gili Air, Terawangan dan Gili Meno, merupakan sektor andalan dan sangat ditentukan oleh faktor keamanan dan kondisi perekonomian global. Bencana alam gempa bumi yang terjadi tahun 2018 dengan isu Tsunami yang sangat cepat menyebar seiring dengan kemajuan telekomunikasi, dimana informasi sangat cepat sampai di masyarakat dunia, sangat berpengaruh pada perekonomian Kabupaten Lombok Utara, dimana sektor pariwisata terdampak, tamu baik domestik maupun mancanegara tidak ada yang berani berkunjung ke tiga Gili.

\section{Gambar 1 Peta Kemiskinan di Kabupaten Lombok Utara}

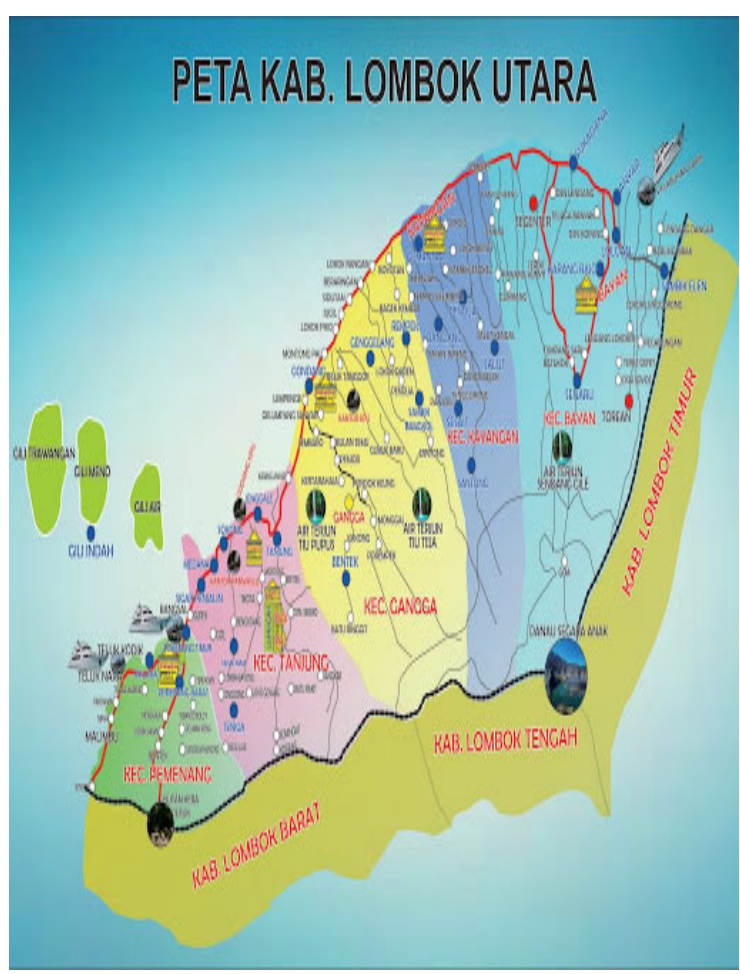

Sumber: BPS Kabupaten Lombok Utara
Data Peta Kemiskinan akan berguna untuk menentukan target secara tepat untuk program bantuan sosial. Jika pemerintah daerah, misalnya, ingin melaksanakan sebuah program terkait kemiskinan dan ketimpangan, informasi dari peta kemiskinan ini dapat digunakan sebagai basis lokasi kecamatan atau desa yang diprioritaskan untuk mendapatkan program.

Adapun data peta kemisikinan pada tingkat kecamatan dan Desa yang ada di Kabupaten Lombok Utara dapat dilihat pada tabel berikut :

Tabel 7. Jumlah Penduduk Miskin Pada Setiap Kecamatan Di Kabupaten Lombok

\begin{tabular}{|l|l|c|}
\hline \multicolumn{3}{|c|}{ Utara } \\
\hline No & \multicolumn{1}{|c|}{ Nama } & $\begin{array}{c}\text { Jumlah } \\
\text { Penduduk } \\
\text { miskin (Orang) }\end{array}$ \\
\hline 1 & Tanjung & 2594 \\
\hline 2 & Bayan & 1585 \\
\hline 3 & Kayangan & 1071 \\
\hline 4 & Gangga & 507 \\
\hline 5 & Pemenang & 495 \\
\hline
\end{tabular}

Sumber : Diolah

Berdasarkan pada tabel di atas diketahu bahwa jumlah penduduk miskin di Kabupaten Lombok Utara adalah di Kecamatan Tanjung jumlah penduduk miskin sejumlah 2594 orang dan Kecamatan Bayan menempat urutan kedua dengan sejumlah penduduk miskin 1585.

Dengan demikian jika pemerintah ingin melaksanakan program yang terkai 
kemiskinan hendaknya di priotaskan Kecamatan Tanjung. Desa yang terbanyak penduduk miskin secara berut nampak pada table 8 berikut :

Tabel 8 Jumlah Penduduk miskin di KLU

\begin{tabular}{|c|c|c|c|}
\hline No & $\begin{array}{l}\text { Nama } \\
\text { Desa }\end{array}$ & $\begin{array}{l}\text { Jumlah } \\
\text { Penduk } \\
\text { Miskin } \\
\text { (Jiwa ) }\end{array}$ & $\begin{array}{c}\text { Lokasi } \\
\text { Kecamatan }\end{array}$ \\
\hline 1 & Sokong & 932 & Tanjung \\
\hline 2 & $\begin{array}{l}\text { Sigar } \\
\text { Penjalin }\end{array}$ & 926 & Tanjung \\
\hline 3 & $\begin{array}{l}\text { Sambik } \\
\text { Elen }\end{array}$ & 541 & Bayan \\
\hline 4 & Sesait & 481 & Kayangan \\
\hline 5 & $\begin{array}{l}\text { Pemenang } \\
\text { Barat }\end{array}$ & 391 & Pemenang \\
\hline
\end{tabular}

Sumber: Data Diolah

Berdasarkan pada tabel di atas bahwa yang paling banyak pendukduk miskinnya adalah terdapat pada Desa Sokong dan Desa Segar Penjalin dan setelah itu pada Desa yang terbanyak penduduk miskin berikutnya.

\section{KESIMPULAN DAN SARAN}

\section{Kesimpulan}

Berdasarkan hasil peneltian dan perhitungan yang telah dilakukan dengan Analisis Location Quotiont (SLQ dan DLQ), Analis Regresi Sederhana dan Peta Kemiskinan dengan menggunakan data PDRB Kabupaten Lombok Utara dan PDRB Provinsi Nusa Tenggara Barat dan Jumlah penduduk miskin di Kabupaten Lombok
Utara yang telah dibahas dalam bab IV dapat simpulkan sebagai berikut :

1. Berdasarkan Analisis SLQ dan DLQ diketahui bahwa dari 17 sektor ekonomi dalam PDRB kabupten Lombok Utara terdapat 6 sektor unggulan yaitu sektor Pengadaan Listrik dan Gas, sektor Pengadaan Air, Pengolahan Sampah,Limbah, dan Daur Ulang, sektor Kontruksi, sektor Inormasi dan komunikasi, sektor Adm Pemerintahan, pertahanan, Jaminan Sosial Wajib dan sektor Jasa Kesehatan dan Kegiatan sosial

2. Berdasarkan Analisis Regresi sederhana diketahui bahwa hubungan antara pertumbuhan ekonomi dan perkembangan jumlah penduduk miskin menunjukkan huhubungan yang berlawanan arah artinya jika pertumbuhan ekonomi meningkat maka jumlah penduduk miskin menurun. Hal ini ditunjukan pada grafik garis pertumbuhan ekonomi dengan trend meningkat di satu sisi garis jumlah penduduk miskin menunjukkan arah pergerakan dengan trend menurun.

3. Peta Jumlah penduduk miskin di Kabupaten Lombok Barat menunjukan bahwa jumlah penduduk miskin yang terbanyak adalah pada Kecamtan 
|80 Muhammad Afwi, Putu Karismawan, I Dewa Ketut Yudha S/Analisis Sektor Ekonomi ...

Tanjung dengan jumlah 2594 orang yang tersebar pada 7 Desa dan Desa yang terbanyak penduduk miskin terdapat di Desa Sokong sejumlah 932 orang dan Desa Segar Penjaling sejumlah 925 orang penduduk miskin.

\section{Saran}

1. Untuk dapat meningkatkan pertumbuhan ekonomi hendaknya pembangunan ekonomi lebih di arahkan pada sektor-sektor ekonomi unggulan saat ini dan masa datang.

2. Pertumbuhan ekonomi hendak diusahan tetap ada peningkatan agar penduduk miskin dapat diturunkan karena adanya pertumbuhan ekonomi akan berpengaruh terhadap perluasan kesempatan kerja sehingga jumlah penduduk miskin menurun.

3. jika pemerintah ingin melaksanakan program yang terkai kemiskinan hendaknya dipriotaskan Kecamatan dan Desa yang terbanyak jumlah penduduk miskin.dalam dalam penelitian ini adalah Kecamatan Tanjung yang meliki 2 Desa terbanyak penduduk miskin di Kabupaten Lombok Utara yaitu Desa Sokong dan Desa Segar Penjali

\section{DAFTAR PUSTAKA}

Arsyad, Lincolin, 1992, Ekonomi Pembangunan, STIE YKPN, Yogyakarta.

Azis, Iwan Jaya, 1994, Ilmu Ekonomi Regional dan Beberapa Aplikasinya di Indonesia, Lembaga Penerbit, Fakultas Ekonomi Universitas Indonesia.

Bendavid-Val, Avrom, 1991, Regional and Local Economic Analysis for Practioners, Praeger Publisher, Fourt Edition, New York and London.

Hoover, Edgar M., 1975, An Introduction to Regional Economics, Alfred A. Knopf, NewYork, Second Edition.

Irmanelly dan Saleh A, 2013. Analisis Sektor Unggulan dan Hubungannya dengan ketenaga kerjaan dan kemiskinan di Provinsi Jambi, Jurnal Development Volume 1 no1.

Kadariah, 1985, Ekonomi Perencanaan, Lembaga Penerbit, Fakultas Ekonomi UniversitasIndonesia, Jakarta.).

Martono, Pan Budi, 2007,Perencanaan Pengembangan Ekonomi Masyarakat Kabupaten GorutBadan Perencanaan Daerah Kabupaten Gorontalo. Limboto Maulana Yusuf, 1999. Ekonomi dan Keuangan Indonesia (EKI) Volume XLVII No 2 
Richardson, H., W., 1977. Dasar-dasar Ilmu Ekonomi Regional, (terjemahan paul Sihotang), Lembaga Penerbitan, FE-UI, Jakarta.

Setiawan dan I Dewa Made Darma, 2012. Peranan Sektor Unggulan terahadap pertumbuhan Ekonomi Daerah, Pendekatan Inputi Output Multiregional dan Interegional, Jawa Timur, Bali dan NTB, Jurnal Sosial Ekonomi(S.I) Nov 2012 ISSN 2615-6628.

Suryana, 2000. Ekonomi Pembangunan, Problema dan Pendekatan, Penerbit Salemba Empat, Jakarta.

Sjafrizal, 1997. Pertumbuhan Ekonomi Wilayah Indonesia Bagian Barat, Prisma No 3 LP3SJakarta 2008, Ekonomi Regional : Teori dan Aplikasi, Baduose Media, Padang

Tarigan, R. 2012. Ekonomi Regional Teori dan Aplikasi, PT Bumi Aksara, Jakarta.

Widodo, Tri 2006, Perencanaan Pembangunan Aplikasi Komputer Era Otonomi Daerah, Yogyakarta 